\title{
Judiciário e Política no Brasil Contemporâneo: Um Retrato do Supremo Tribunal Federal a partir da Cobertura do Jornal Folha de S. Paulo*
}

\section{Fabiana Luci de Oliveira ${ }^{1}$}

${ }^{1}$ Universidade Federal de São Carlos (UFSCar), São Carlos, SP, Brasil. E-mail: fabianaluci@ufscar.br

\section{APRESENTAÇÃO}

$\mathrm{T}$ ornou-se quase lugar-comum afirmar o protagonismo do Supremo Tribunal Federal (STF) no cenário político brasileiro contemporâneo, sobretudo via utilização dos conceitos de judicialização da política e de ativismo judicial ${ }^{1}$.

Esse debate, em grande parte, é travado com base nas decisões do STF envolvendo a regulação da vida política, econômica, social e moral do país, e da constatação do aumento da cobertura midiática da instituição e dos seus ministros, especialmente a partir de 2005, quando a mídia passou a dar grande atenção às decisões da justiça em episódios de punição à corrupção política, primeiro com o caso do Mensalão e depois com a operação Lava-Jato.

Mais recentemente, o processo de impeachment de Dilma Rousseff e o afastamento de Eduardo Cunha do mandato e da presidência da Câmara dos Deputados dirigiram os holofotes da mídia com maior intensidade ao STF. Nesse contexto, a instituição e seus ministros ganham cada vez mais visibilidade.

O objetivo deste artigo é tratar dessa visibilidade, qualificando-a a partir da cobertura da grande imprensa. Buscamos, mais especificamente,

\footnotetext{
* A pesquisa contou com o suporte financeiro da Fundação de Amparo à Pesquisa do Estado de São Paulo (Fapesp). A autora agradece os dois pareceristas anônimos por suas críticas e sugestões ao trabalho.
}

DADOS - Revista de Ciências Sociais, Rio de Janeiro, vol. 60, no-4, 2017, pp. 937 a 975. 
descrever como o jornal Folha de S. Paulo (FSP) retratou a atuação do STF e de seus ministros entre os anos de 1999 e 2014, enfocando o tipo de cobertura predominante (política ou jurídica) e os temas de maior recorrência no enquadramento da instituição. Buscamos verificar, também, em que medida essa cobertura acompanha as ações efetivas do tribunal em controle concentrado de constitucionalidade, examinando quais decisões viraram notícia e com que frequência.

Partindo desses dados descritivos, problematizamos a imagem pública que vem sendo construída do STF e dos seus ministros ao longo do tempo e a forma pela qual a mídia vem posicionando a instituição no sistema político do país, no sentido de melhor compreender a percepção da presença do STF no cenário público brasileiro.

\section{ESTUDOS SOBRE JUDICIÁRIO E MÍDIA}

A mídia desempenha papel vital na legitimação do Judiciário nas democracias ocidentais, sobretudo das Supremas Cortes (Gibson, Caldeira, Baird, 1998; Miljan, 2014), contribuindo tanto para reforçar a simbologia da imparcialidade judicial, quanto para traduzir as decisões dos tribunais, explicando ao grande público o sentido das decisões e os termos técnicos típicos da linguagem jurídica.

Os estudos sobre as relações da Suprema Corte norte-americana com a mídia, em obras como as de Slotnick (1992), Caldeira e Gibson (1992) e Gibson, Caldeira e Baird (1998), apontam que a cobertura dos meios de comunicação de massa é fundamental para a compreensão que os cidadãos têm do tribunal. Slotnick (1992), por exemplo, afirma que a mídia é o principal elo entre a população e a Suprema Corte, na medida em que informa os cidadãos sobre as atividades, os defeitos e as qualidades do tribunal, assim como das demais instâncias de poder.

No entanto, diferente dos demais poderes, a Suprema Corte é mais dependente da mídia para manter sua legitimidade e garantir que suas decisões sejam respeitadas e seguidas. Isso porque os Justices (juízes da Suprema Corte norte-americana) não são eleitos pelo voto popular e frequentemente são chamados a decidir questões polêmicas, muitas vezes contrariando a opinião pública; assim, precisam do apoio da mídia para gerar conscientização e confiança (Caldeira, Gibson, 1992). Entre as estratégias de legitimidade estaria o reforço dos símbolos que distanciam a corte dos demais poderes políticos (como os ideais de ob- 
jetividade judicial e imparcialidade), estabelecendo uma imagem de instituição apolítica.

A Suprema Corte norte-americana mantém fechadas e distante dos olhos do público as sessões em que os ministros debatem e deliberam sobre os casos, e seus ministros raramente falam com os jornalistas ou dão entrevistas. Já no Brasil as sessões colegiadas do STF são abertas e transmitidas ao vivo pela TV Justiça, que existe desde 2002, e os ministros frequentemente falam com os jornalistas e dão entrevistas. Mas mesmo com essa diferença nos níveis de publicidade da sua atuação, em ambos os países os níveis de conhecimento exibidos pela população sobre o que a Corte faz e como suas decisões afetam a vida cotidiana dos cidadãos são baixos e dependentes quase que exclusivamente do que a mídia reporta (Johnson, Socker, 2012; Falcão, Oliveira, 2013) ${ }^{2}$.

Nossa pesquisa não tem intenção comparada, mas se baseia nas metodologias utilizadas nos estudos sobre a Suprema Corte norte-americana, ${ }^{3}$ assumindo que a mídia é peça-chave na construção e preservação da legitimidade pública do Supremo Tribunal Federal. Argumentamos que a representação dos meios de comunicação sobre o STF influencia diretamente o nível de confiança da população na instituição e suas percepções acerca da eficácia e da legitimidade decisória dessa corte. Isso porque a grande maioria dos brasileiros não tem contato direto com o tribunal, dependendo da mídia para saber o que é o STF, qual é o seu papel no sistema político brasileiro e como ele tem se saído no desempenho desse papel. Mas o que exatamente a mídia tem dito sobre o STF e como tem retratado a performance do tribunal? Essas são as questões descritivas centrais que visamos responder neste artigo.

Os estudos sobre a Suprema Corte norte-americana utilizam, principalmente, a análise de conteúdo de notícias sobre o tribunal ao longo do tempo, aplicando a análise eletrônica de corpus linguístico para verificar, nessas notícias, o padrão de uso de palavras e frases que remetem a um enquadramento mais político ou mais apolítico da corte. Os resultados têm mostrado como a cobertura da imprensa tende a politizar a Suprema Corte, fornecendo informações sobre a natureza política das decisões, em vez de reforçar a ideia de neutralidade, caracterizando os juízes como atores ideológicos e descrevendo as decisões do tribunal como inerentemente políticas, impulsionadas mais por preferências pessoais do que por aspectos técnicos, doutrina constitucional 
e precedentes legais (Spill e Oxley, 2003; Johnson e Socker, 2012; Jones, 2014).

Nos termos de Spill e Oxley (2003), a mídia tem retratado a Suprema Corte mais como instituição política, semelhante às outras instituições governamentais, do que como "oráculo apolítico", que toma decisões de forma imparcial, interpretando tecnicamente o sentido da Constituição.

Nessa linha, nos baseamos em Johnson e Socker (2012), que classificam a cobertura jornalística sobre a Suprema Corte em jurídica e política (legal coverage and political coverage), argumentando que há três conjuntos de fatores que a impulsionam: ações, facções e interações.

Por ações, os autores entendem as decisões do tribunal. E como a maioria da população não tem contato pessoal com a corte e suas decisões, a mídia se torna um dos principais canais informativos das ações institucionais ao cidadão. E quanto mais a corte decide, quanto maior o volume de casos, mais material há disponível para ser reportado. Os autores argumentam que as ações que mudam o status quo são aquelas que atraem maior atenção da mídia.

Por facções, entendem o recorte ideológico (conservadores x liberais) e as divisões internas do tribunal nas decisões (quem vota com quem), afirmando que as decisões que dividem a corte são as que atraem maior atenção da mídia, construídas como casos polêmicos.

E, finalmente, por interações referem-se ao relacionamento do tribunal com os outros ramos mais conhecidos do governo, Executivo e Legislativo, cobrindo a posição do tribunal no sistema federal mais amplo.

Com base nesses três fatores procuram explicar tanto o volume da cobertura midiática da Suprema Corte, quanto o enquadramento predominante (político x jurídico). Ou seja, o tipo de cobertura depende dos casos que a corte decide, de como se dá a dinâmica interna no processo decisório e de como a corte se insere no sistema político mais amplo, interagindo com os demais poderes.

Como o interesse dos autores está em identificar a incidência de notícias voltadas às questões legais e às implicações políticas das ações da Suprema Corte, utilizam a análise de conteúdo computadorizada da cobertura do tribunal pela Associated Press, entre 1979 e 2006, em busca da prevalência de palavras e frases específicas aos tipos de qua- 
dros (político ou jurídico), valendo-se de uma lista predefinida de termos que capturam o sentido jurídico-legal ou político do enquadramento ${ }^{4}$. E considerando que os quadros competem por espaço dentro das notícias, trabalham com a média de termos com sentido político em comparação com a média de termos com sentido jurídico ao longo do tempo.

Concluem que a atenção da mídia é maior quando há mais decisões em sentido liberal e quando a Suprema Corte derruba legislação, declarando a inconstitucionalidade de leis, e também quando há eventos atípicos, sobretudo aposentadorias e nomeações de novos juízes.

Outro a se basear na análise de conteúdo é Jones (2014), rastreando nas notícias do The New York Times que mencionam a Suprema Corte, entre 1950 e 2009, o uso de sinais linguísticos que são considerados como politização: caracterização do perfil ideológico dos Justices (liberais ou conservadores); vinculação ideológica do Justice ao Presidente que o nomeou, sugerindo submissão; cobertura das decisões que dividiram a corte (votação 5-4), em comparação ao peso que elas têm na totalidade de decisões do tribunal.

O autor observou um aumento significativo na incidência dos termos linguísticos associados à politização da instituição ao longo do tempo, sobretudo da menção ao termo "conservador", vinculado tanto aos juízes quanto às decisões da corte.

Utilizamos metodologia semelhante para classificar a cobertura da FSP sobre o STF, observando o enquadramento feito pelo jornal ao longo de quatro governos diferentes: o segundo mandato de Fernando Henrique Cardoso na Presidência da República (1999-2002); o primeiro e o segundo mandatos de Luiz Inácio Lula da Silva (2003-2006 e 2007-2010) e o primeiro mandato de Dilma Rousseff (2011-2014). Interessa-nos identificar qual o tipo de moldura que predominou no período, a partir do uso de determinadas palavras e frases que remetam a um sentido político ou jurídico, observando se houve variações significativas ao longo do tempo.

Nos baseamos, ainda, em estudo de O'Callaghan e Dukes (1992), que investigaram a seletividade da cobertura midiática, valendo-se das teorias de agenda-setting. Os autores observaram o ano (term) de 1986-1987, quando a Suprema Corte norte-americana decidiu 153 casos com opiniões escritas, e buscaram identificar, a partir da classifica- 
ção dos temas decididos, a repercussão midiática que cada decisão teve, examinando em que medida essa cobertura espelhou ou não o volume de trabalho do tribunal.

Como fonte de dados da cobertura midiática, O'Callaghan e Dukes (1992) utilizaram dois repositórios de notícias escritas e televisivas (Vanderbilt Television News Abstracts e Reader's Guide to Periodical Literature) e três jornais escritos (The New York Times, Los Angeles Times e Chicago Tribune), pesquisando, no total da cobertura da Suprema Corte, qual a quantidade de notícias dedicadas às questões decididas pelo tribunal entre 1986-1987. Observaram um descompasso entre as questões de interesse midiático e as temáticas sobre as quais a corte decidiu: decisões econômicas apareceram com menor frequência do que a sua proporção no volume de trabalho do tribunal; decisões relativas à Primeira Emenda receberam cobertura em excesso e casos de direitos civis também receberam cobertura superior a sua proporção no número total de casos decididos pelo tribunal (1992:197).

Buscamos no estudo da cobertura da FSP observar, também, a relação entre os temas decididos pelo STF em controle concentrado de constitucionalidade e sua presença na mídia, verificando se há discrepância ou concordância entre o que o tribunal decide e o que é noticiado: os temas mais relatados pela Folha de S. Paulo são os mais frequentes na pauta do Supremo?

\section{ESTUDOS SOBRE A COBERTURA MIDIÁTICA DO STF}

Como já pontuado, a atuação do STF no nosso cenário político recente, em casos como o Mensalão, a operação Lava-Jato e o impeachment de Dilma Rousseff, levou a mídia a dar grande visibilidade ao tribunal, noticiando-o cada vez mais. Falcão e Oliveira (2013), por exemplo, observaram a intensificação das relações do STF com a sociedade e a opinião pública, mostrando um crescimento significativo da presença do tribunal na mídia ao longo dos anos 2000, quando passou a decidir com maior frequência sobre temas de impacto no cotidiano dos cidadãos, e apontam que, com o julgamento da Ação Penal 470 (o Mensalão), em 2012, o STF tornou-se não apenas mais noticiado como também mais conhecido do grande público.

O protagonismo político do STF pode estar mais visível agora, mas seguramente não teve início com o Mensalão. Oliveira (2004) mostrou, a partir da análise de conteúdo da cobertura sobre o STF nos jor- 
nais Folha de S. Paulo e O Estado de S. Paulo, em notícias publicadas entre 1979 e 1999, como a mídia foi um importante canal para a mudança da imagem pública dessa instituição no processo de transição democrática. A autora observou que esses jornais retrataram o STF como uma instituição alheia à situação econômica, política e social do país durante todo o regime militar, e que a partir da abertura política o tribunal iniciou um movimento de aproximação com os meios de comunicação no sentido de alterar essa imagem.

Esse movimento foi inaugurado pelo ministro Xavier de Albuquerque ao assumir a presidência do tribunal em 1981, quando organizou um encontro com jornalistas e proprietários de jornais no sentido de acabar com o distanciamento existente entre o STF e a opinião pública. $\mathrm{Na}$ ocasião, o ministro declarou que era necessário resgatar o tribunal "das páginas mais modestas da imprensa para as mais destacadas e condizentes com a sua importância institucional" (apud Oliveira, 2004:105).

E a busca pela proximidade com a imprensa seguiu ao longo da década de 1980, com presença constante do STF nos jornais, até a Constituinte. Oliveira (2004) identificou uma série de declarações, entrevistas e mesmo artigos dos ministros nesses jornais, em defesa de garantias e ferramentas institucionais para manutenção e expansão dos poderes políticos da instituição, afirmando, no sentido proposto por Garapon (1999), o uso estratégico da mídia pelos juízes, seja para aproximar a justiça da população, seja para defender-se de críticas, ou ainda para fazer avançar uma agenda de interesses corporativos.

Com as garantias conquistadas na Constituição de 1988, o STF passou a ocupar um espaço maior no cenário político do país e, com isso, segundo Oliveira (2004), as clivagens ideológicas entre os ministros começaram a ser mais destacadas, com os jornais cobrindo com maior frequência o perfil de atuação dos ministros, classificando-os como técnicos ou políticos, com base em suas decisões.

Na década de 1990 ganhou proeminência o processo de nomeação de ministros ao STF, em especial pela indicação e posse dos ministros Carlos Mário da Silva Velloso, Marco Aurélio Mendes de Farias Mello e Ilmar Nascimento Galvão. Oliveira (2004) afirma que a cobertura nessa década delineou a imagem de um tribunal politicamente ativo. Entre diversos exemplos, traz falas dos próprios ministros publicadas nos jornais, como a afirmação de Sepúlveda Pertence de que "estamos 
cada vez mais longe da imagem de bons velhinhos do Supremo" (apud Oliveira, 2004:110), e a declaração de Sydney Sanches de que "o STF não pode deixar de considerar o momento político e econômico por que passa o país na época de seus julgamentos" (idem).

Houve também, de acordo com a autora, uma intensificação na cobertura das tensões do tribunal com os poderes Executivo e Legislativo, sinalizando a disputa por espaço na tomada de decisão acerca dos rumos políticos do país. Entre os episódios de destaque na mídia nesse período estiveram a atuação do tribunal no processo de impeachment do presidente Fernando Collor de Mello e as críticas do então presidente do Senado, Antônio Carlos Magalhães, ao então presidente do STF, ministro Carlos Velloso, em decorrência da atuação do tribunal nas diversas Comissões Parlamentares de Inquérito (CPIs) em andamento (dos bancos, do narcotráfico, do Judiciário).

Um dos aspectos de interesse de Oliveira (2004), que nos aproxima de sua pesquisa, era observar se as notícias sobre o STF privilegiavam a cobertura do papel político ou jurídico da instituição. Por papel político a autora classificou a cobertura que ou reivindicava ou afirmava explicitamente o desempenho de um papel político por parte do tribunal, e por papel jurídico, classificou a cobertura de sua atuação como última instância do Judiciário, e julgamentos de temáticas de direitos individuais, especialmente habeas corpus e pedidos de extradição. Oliveira encontrou em $38,4 \%$ das notícias publicadas no jornal FSP, no período de 1979-1988, referência ao papel político do STF, e em 19,2\%, referência ao papel jurídico da instituição (Oliveira, 2004:109). Já no período de 1994-1999, 54\% das notícias traziam referência ao papel político do STF e $17 \%$ ao papel jurídico (ibidem:115). Dessa forma, mostra como já na década de 1990 predominava na cobertura midiática o protagonismo político do STF.

Há uma série de evidências empíricas da intensificação das relações entre o STF e a opinião pública. Além do crescimento da cobertura midiática, pesquisas de opinião têm mostrado que o STF tornou-se mais conhecido do grande público e que os brasileiros estão acompanhando mais atentamente as decisões do tribunal ${ }^{5}$. A criação da TV Justiça, em 2002, com o televisionamento dos julgamentos, tornou também mais fácil e acessível cobrir a atuação do STF. Esse cenário levou analistas da conjuntura política a criticarem a politização excessiva e o ativismo ju- 
dicial anticorrupção, falando-se mesmo do perigo de um governo de juízes ${ }^{6}$.

Embora careça de uma definição precisa, a expressão "governo de juízes" possui riqueza de significado, transmitindo a ideia do envolvimento do Judiciário nas decisões sobre políticas públicas e na disputa político-eleitoral, tendo a última palavra nesses âmbitos, implicando uma substituição ao Executivo e ao Legislativo (Davis, 1987).

Essa substituição pode ser lida em duas chaves. Uma abertamente negativa, indicando invasão ou usurpação de competências decisórias dos poderes políticos eleitos, criticando o STF por atuar como uma espécie de terceira casa legislativa, criando novas regras. Outra mais positiva, afirmando não haver invasão de competência, mas ocupação do espaço abandonado pelos políticos, com o STF fazendo valer dispositivos constitucionais não regulamentados ou mesmo preservando a Constituição frente a potenciais retrocessos legislativos.

Analisamos a cobertura do jornal FSP sobre o STF buscando rastrear evidências dessas duas chaves, observando em quais situações e contextos aparecem e qual o enquadramento predominante. Consideramos que parte dos questionamentos que analistas de conjuntura levantam quanto ao protagonismo do STF no cenário político atual nasceram com a aproximação do STF com a mídia, não sendo novidade. A novidade estaria na constatação de que se exacerbaram. Em nosso estudo investigamos evidências dessa exacerbação.

Outra pesquisa com a qual dialogamos é a de Biroli e Mantovani (2014), que trata de um caso específico, o julgamento do Mensalão, e não diretamente das relações do STF com a mídia. As autoras pesquisaram a cobertura do Mensalão pelo jornal Folha de S. Paulo em 236 notícias, publicadas entre agosto e novembro de 2012, analisando o enquadramento predominante na veiculação desse caso.

Diferenciando o tipo de texto jornalístico entre noticioso (reportagens e entrevistas) e opinativo (colunas, artigos e editoriais), as autoras concluem que há uma ênfase maior no aspecto técnico do julgamento nos textos noticiosos e um maior destaque para os aspectos políticos do julgamento nos textos opinativos, mas que, na média, os dois enquadramentos, político e técnico, têm a mesma incidência no jornal (41,1\% cada). 
Não nos interessa diferenciar o tipo de texto jornalístico, como fizeram as autoras, mas trabalhamos buscando, como elas, a incidência de categorias que indicam o tipo de enquadramento, como político ou técnico (jurídico), ao longo de dezesseis anos de cobertura da FSP sobre o STF. Empregamos a mesma concepção de enquadramento usada por Biroli e Mantovani, como narrativas ou "eixos de organização dos sentidos na cobertura jornalística, que compõem quadros interpretativos a partir de pressupostos que compartilham, potencialmente, com os leitores" (Biroli, Mantovani, 2014:213).

\section{O SUPREMO NO JORNAL FOLHA DE S. PAULO}

\section{Enquadramento temático}

Escolhemos analisar a cobertura do STF pela FSP por ser o jornal nacional de maior tiragem e circulação ${ }^{7}$. Adotamos aqui a posição de Miguel e Biroli (2011:81) de que, apesar da expansão da internet e das mídias sociais, os meios convencionais de mídia seguem como "os grandes centros produtores de informação", mantendo-se na "posição central nas disputas pela construção simbólica do mundo social e pela definição das preferências" (Miguel, Birolli, 2011:82).

Selecionamos eletronicamente todas as notícias publicadas no jornal FSP entre 01/01/1999 e 31/12/2014 ${ }^{8}$ que retornaram para o termo de busca "Supremo Tribunal Federal". Nesse levantamento inicial encontramos 32.441 notícias.

Notamos em todo o período investigado uma tendência de crescimento ano a ano da cobertura do tribunal, com dois picos: um primeiro em 2009, ano em que foram julgados casos como a extradição de Cesare Battisti (Extradição [EXT] 1.085), a derrubada da exigência de diploma para o exercício da profissão de jornalista (Recurso Extraordinário [RE] 511.961) e a revogação da lei de imprensa (Arguição de Descumprimento de Preceito Fundamental [ADPF] 130), além de acontecimentos como o falecimento do ministro Menezes Direito e a nomeação e posse do ministro Dias Toffoli; o segundo pico se deu em 2012, devido, sobretudo, ao julgamento do Mensalão.

A esse levantamento inicial, aplicamos um filtro temático, selecionando para o nosso corpus de análise apenas as notícias que se referiam ao STF ou a seus ministros como atores centrais, trazendo no título pelo menos um dos seguintes termos: STF; Supremo(a); Corte; Judicial; 
Gráfico 1

Incidência de notícias sobre o "Supremo Tribunal Federal" no jornal Folha de S.

Paulo por ano, entre 1999 e 2014

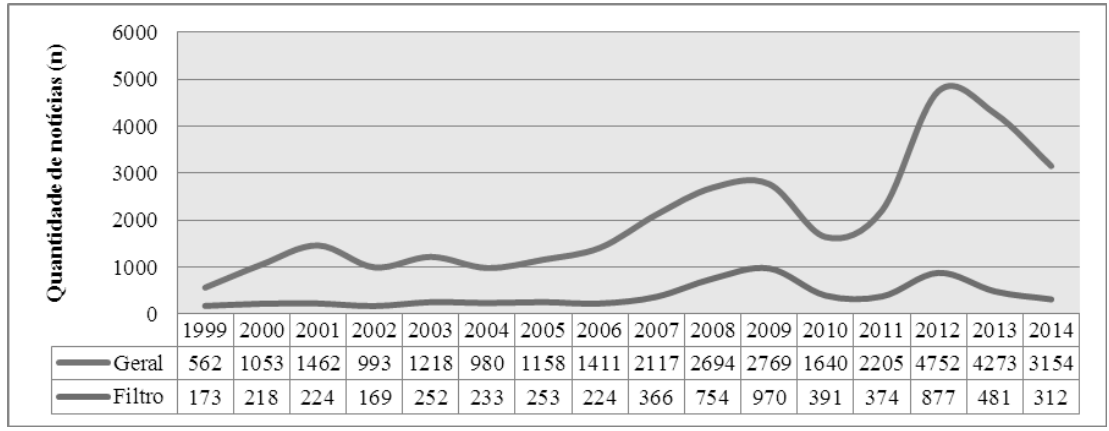

Jurídico; Judiciário; Justiça; Ministro(a); nome de um(a) ministro(a) que integrasse a corte no ano de referência da busca. Feita essa filtragem inicial, para as notícias que não se enquadraram no critério temático, aplicamos um segundo filtro: autoria, incluindo em nossa amostra aqueles artigos que fossem de autoria de algum(a) ministro(a) do STF.

Os filtros temático e autoral foram utilizados para reduzir o volume de notícias a ser analisadas, deixando no corpus apenas aquelas cujo foco fosse o STF ou seus ministros. Após a aplicação desses filtros, o corpus de análise foi constituído por 6.271 notícias, sendo que o volume de notícias no filtro acompanha a tendência geral observada no jornal, com os dois picos em 2009 e 2012 (ver Gráfico 1).

Para responder aos nossos questionamentos descritivos centrais, sobre o que a opinião pública fala quando o assunto é o STF e como a mídia tem retratado a performance do tribunal, procedemos à análise de conteúdo desses 6.271 textos, desenvolvendo as categorias de enquadramento. Para essa classificação, nos baseamos na teoria fundamentada (Strauss, Corbin, 2008), descrevendo as narrativas presentes nas notícias e buscando identificar padrões e relações nessas narrativas, para construir categorias analíticas mais abrangentes.

Considerando que o eixo central de interesse está no tipo de enquadramento predominante da instituição, se político ou jurídico, ou seja, se nas questões técnico-legais ou nas implicações e consequências políticas das suas ações, utilizamos como ponto de partida o argumento já mencionado de Johnson e Socker (2012) dos três conjuntos de fatores 
que impulsionam a cobertura midiática da corte (ações, facções e interações), tratando-os como diferentes dimensões.

Na dimensão de "ações", classificamos as notícias que tratam dos casos decididos pelo STF, considerando o tipo de caso em questão. Assim, trabalhamos a partir de três categorias:

1. judicialização anticorrupção e julgamento de autoridades políticas, reunindo as notícias que versam sobre a atuação do STF em casos de corrupção, julgamento de ações penais e inquéritos de autoridades com foro por prerrogativa de função;

2. judicialização de políticas públicas, agrupando as notícias sobre casos de controle concentrado de constitucionalidade no STF, cobrindo as decisões e seus impactos. Essa categoria reúne as notícias referentes aos tipos de casos que Falcão, Cerdeira e Arguelhes, (2011) atribuem à persona constitucional do STF e se referem ao fenômeno que Hirschl (2008) designa por "judicialization of public policy-making";

3. última instância do Poder Judiciário, categoria que agrupa as notícias referentes ao papel do STF como última instância do Poder Judiciário, tratando de sua competência recursal (recursos extraordinários e agravos de instrumento), e também da competência ordinária (mandados de segurança, reclamações, habeas corpus, extradição e intervenção federal), reunindo aqui os tipos de casos que Falcão, Cerdeira e Arguelhes, (2011) atribuem às personas recursal e ordinária do STF.

Na dimensão de "facções" classificamos as notícias que tratam do recorte ideológico e das divisões internas do tribunal, incluindo a cobertura de nomeações e aposentadorias, assim como notícias sobre ex-ministros do STF, a partir de três categorias:

4. perfil dos ministros, categoria que agrupa as notícias que tratam de quem são os ministros, qual seu estilo de atuação (ideologia), além da cobertura de nomeações e posses no tribunal, eleição para a presidência, aposentadoria etc.

5. divisões internas e tensões, reunindo notícias que tratam de decisões que dividiram a corte, assim como discussões e tensões entre ministros do STF;

6. ex-ministros do STF, reunindo notícias acerca de ex-ministros e sua atuação pós-STF. 
Já na dimensão de "interações", consideramos as notícias que cobrem a posição do STF no sistema federal mais amplo, tratando do relacionamento do tribunal com os poderes Executivo e Legislativo, incluindo a cobertura do fenômeno da judicialização da política, a crítica da politização da justiça e seu contraponto, a afirmação da imparcialidade. Além disso, consideramos na dimensão de interações o relacionamento do tribunal com as demais profissões do sistema estatal de justiça. Para a dimensão de interações trabalhamos com nove categorias:

7. tensão STF $x$ Poder Executivo, referindo-se às notícias que cobrem situações de tensão e disputa entre STF e Poder Executivo;

8. tensão STF $x$ Poder Legislativo, referindo-se às notícias que cobrem situações de tensão e disputa entre STF e Poder Legislativo;

9. centralidade política do $S T F$, agrupando as notícias que têm por foco o fenômeno mais amplo do protagonismo político do Judiciário, remetendo ao que Hirschl (2008) designou como "judicialização da megapolítica", quando as regras do jogo são delegadas à deliberação do Judiciário. Essa categoria apresenta um enquadramento positivo do fenômeno da judicialização da política, remetendo à ideia de ocupação de vácuo de poder, tratando as relações do STF com os demais poderes como um jogo de equilíbrio;

10. politização do $S T F$, reunindo notícias que tratam do mesmo fenômeno da judicialização da política, mas com um enquadramento negativo, remetendo às ideias de invasão da lógica da política no campo jurídico e usurpação de competências decisórias;

11. defesa da imparcialidade do $S T F$, reunindo notícias que tratam da afirmação ou defesa da imparcialidade da instituição e sua diferenciação da política partidária, remetendo à ideia de desempenho por parte do STF dos papéis tradicionais do Judiciário e ao perfil tradicional de juiz, em oposição à ideia de politização;

12. engajamento político, reunindo notícias que cobrem declarações individuais de ministros, defendendo posições consideradas polêmicas, classificadas como fala fora dos autos, por se referirem a temáticas que já estejam ou possam chegar à pauta do STF. A categoria engajamento político remete à ideia oposta ao perfil tradicional de juiz (que na definição de Montesquieu é a "boca da lei"); 
13. tensão STF x profissões do sistema de justiça (Ministério Público, polícia etc.), reunindo as notícias que tratam da tensão, disputa e críticas entre STF e demais profissões do sistema de justiça;

14. defesa de interesses corporativos, categoria que agrupa as notícias que tratam de reivindicações financeiras e da organização institucional do Poder Judiciário, incluindo aqui a defesa dos interesses das profissões jurídicas estatais, denotando a existência de relações harmoniosas com as demais profissões jurídicas;

15. reforma do Poder Judiciário, categoria que reúne as notícias que tratam da crise do Poder Judiciário e da necessidade de reformá-lo.

No processo de classificação, consideramos o tema central da notícia, mas, uma vez que uma mesma notícia pode trazer mais de um tema, classificamos temáticas adjacentes. Assim, para cada notícia, classificamos até duas temáticas, sendo que a frequência relativa de incidência foi calculada com base no total de notícias.

Conforme disposto no Gráfico 2, num primeiro retrato que temos da classificação das notícias da FSP sobre o STF no período, vemos que o que move a cobertura são as ações, ou seja, os casos que o STF decide. Mas houve uma mudança: se nos dois primeiros períodos, entre 1999-2002 (segundo governo de Fernando Henrique Cardoso [FHC]) e 2003 e 2006 (primeiro governo Lula), havia equilíbrio entre as dimensões de ações e interações, a partir de 2007 o noticiário concentrou-se

\section{Gráfico 2}

Enquadramento temático das notícias nas dimensões de ações, facções e interações, de acordo com período (governo) (\%)

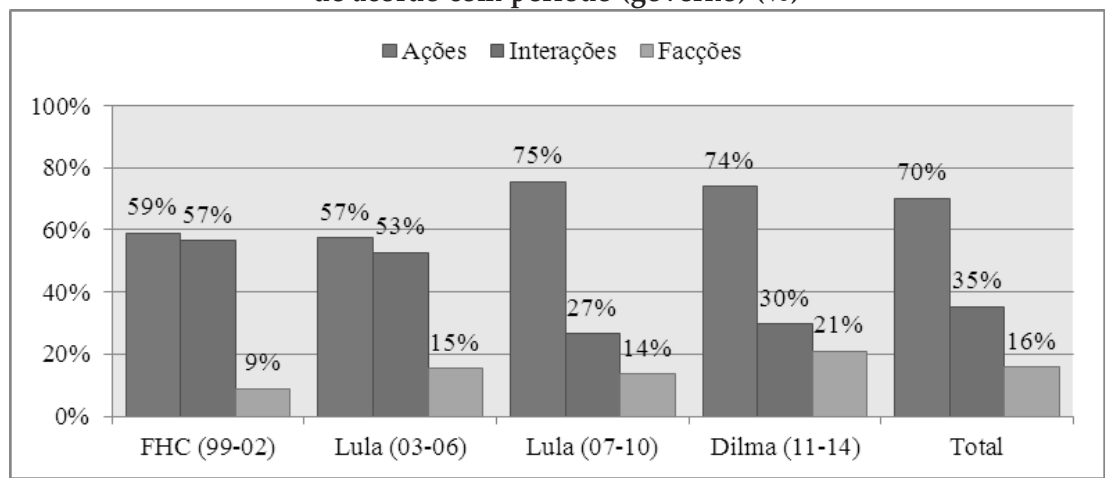

Base: Total: 6.271 notícias; FHC (99-02): 784 notícias; Lula (03-06): 962 notícias; Lula (07-10): 2.481; Dilma (11-14): 2.044 notícias. 
nas ações - não podemos esquecer que 2007 foi o ano em que a Ação Penal (AP) 470 foi protocolada no STF.

Mas sobre o que exatamente a opinião pública fala quando o assunto é o STF? O tema principal das notícias trata de ações na pauta do tribunal (70\% de todas as notícias referiam-se a algum caso em julgamento). Detalhando o conteúdo das notícias na dimensão de ações, vemos, no Gráfico 3, que o principal assunto é a judicialização anticorrupção, envolvendo casos de julgamento de autoridades políticas (29\% do total de notícias trazem essa temática).

Em segundo lugar, com $27 \%$ de incidência, está a judicialização de políticas públicas, principalmente nas esferas da competição política e de direitos sociais e liberdades civis (categoria que será detalhada mais adiante). E em terceiro lugar, com 14\% de incidência, está a atuação ordinária e recursal do STF, sobretudo cobrindo decisões em habeas corpus de políticos e personalidades públicas e casos de extradição.

Na dimensão de interações, as categorias de maior incidência são aquelas que remetem à cobertura política, primeiro com a crítica da politização do tribunal (7\% do total de notícias) e depois com o engajamento político de ministros, dando declarações e posicionando-se publicamente sobre questões polêmicas ${ }^{9}$ e também defendendo os interesses corporativos da magistratura ${ }^{10}(6 \%$ do total de notícias para cada uma das categorias).

\section{Gráfico 3}

Enquadramento temático notícias (\%)

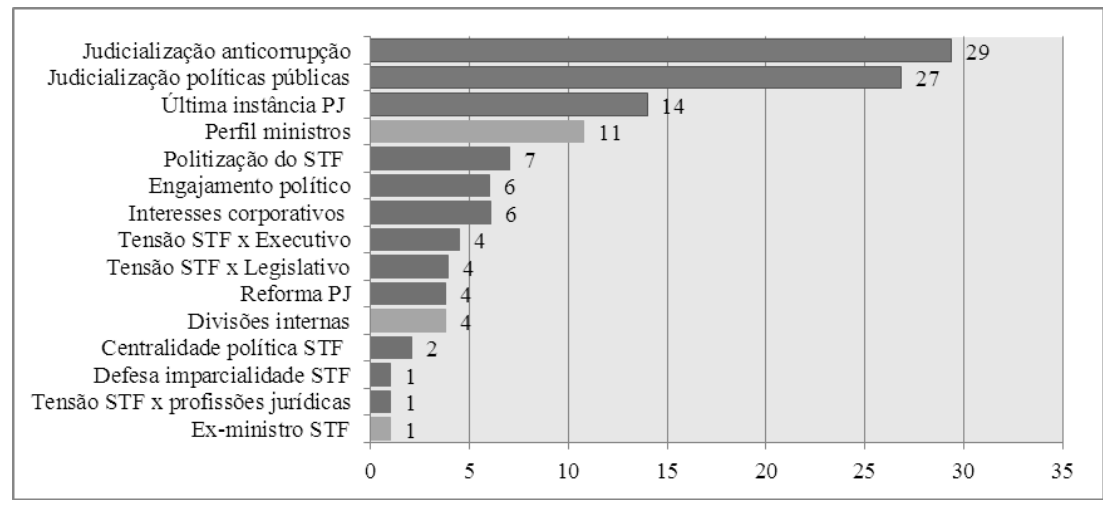

Base: 6.271 notícias. 
Um exemplo da crítica à politização do tribunal e do uso da expressão "governo de juízes" na chave negativa, indicando uma interferência indevida no Poder Legislativo (sentido que predominou na FSP), foi quando da decisão do STF de suspender os processos de seis deputados suspeitos de envolvimento no Mensalão e interferir no processo de cassação do ex-deputado José Dirceu. Em artigo publicado na FSP, afirmou-se que, com essas decisões, o STF desrespeitou o princípio da separação de Poderes e que sem esse respeito "chega-se facilmente ao temido governo dos juízes - no caso do STF, a uma espécie de Terceira Casa Legislativa (soberana e oligárquica)". ("Partido-politização da Justiça Constitucional", FSP, 04/02/2006).

Na sequência, as tensões com os poderes Legislativo e Executivo aparecem com $4 \%$ de incidência cada, mesmo peso dado à temática da reforma do Judiciário.

A centralidade política do STF ("judicialização da megapolítica"), assim como a defesa da imparcialidade do tribunal, e as tensões com as demais profissões jurídicas apresentam baixa incidência (2\% e 1\%, respectivamente). A centralidade política representa a chave positiva do uso da expressão "governo de juízes", indicando ocupação do espaço abandonado pelos políticos, especialmente como resposta à omissão legislativa injustificada ${ }^{11}$.

Já na dimensão de facções, a categoria de maior incidência é o perfil dos ministros, a quarta mais frequente em todo o período, com $11 \%$ das notícias cobrindo a trajetória de carreira e os perfis de votação dos ministros. É mais frequente quando uma nomeação é feita para uma vaga no STF ou quando um ministro assume a presidência do tribunal.

As divisões internas aparecem com $4 \%$ de incidência e referem-se tanto à troca de críticas entre ministros quanto às decisões que dividiram a corte. Por fim, com 1\% de incidência, aparece a categoria que classifica notícias sobre ex-ministros do STF, tendo sido mais frequente no período em que Nelson Jobim assumiu como ministro no governo Lula, compreendendo também as notícias sobre o falecimento de ex-ministros, como em 2012 os ex-ministros Djaci Alves Falcão e Maurício Corrêa e, em 2013, o ex-ministro Luiz Rafael Mayer.

Observando em detalhe a cobertura da FSP sobre o STF ao longo dos governos, é nítida a mudança de chave de enquadramento, com o cres- 
cimento expressivo da incidência da judicialização anticorrupção e a diminuição da judicialização das políticas públicas.

Durante o segundo governo FHC (1999-2002), primeiro período em análise, a principal temática na cobertura do STF era a judicialização de políticas públicas, correspondendo a $34 \%$ das notícias. Entre os casos de destaque nesse período estiveram a privatização de empresas, sobretudo o caso da privatização do Banco Banespa (entre os casos mais noticiados está a Ação Direta de Inconstitucionalidade [ADI] 2.251, requerida pelo Partido dos Trabalhadores (PT) para suspender a Medida Provisória [MP] 1.984), a discussão da cobrança da contribuição previdenciária dos servidores inativos (ADI 2.010), a constitucionalidade da cobrança da Contribuição Provisória sobre Movimentação Financeira [CPMF] (ADI 2.031) e a discussão da constitucionalidade do racionamento de energia elétrica (Ação Declaratória de Constitucionalidade [ADC] 9 e ADI 2.470) [Ver Gráfico 4].

Evidentemente, nas discussões sobre os casos decididos pela corte aparecem frequentemente críticas ou elogios à centralidade do papel desempenhado pelo STF no cenário político nacional. Exemplo disso está na decisão sobre a contribuição previdenciária dos servidores ina-

\section{Gráfico 4}

Enquadramento temático de notícias, de acordo com período (governo) (\%)

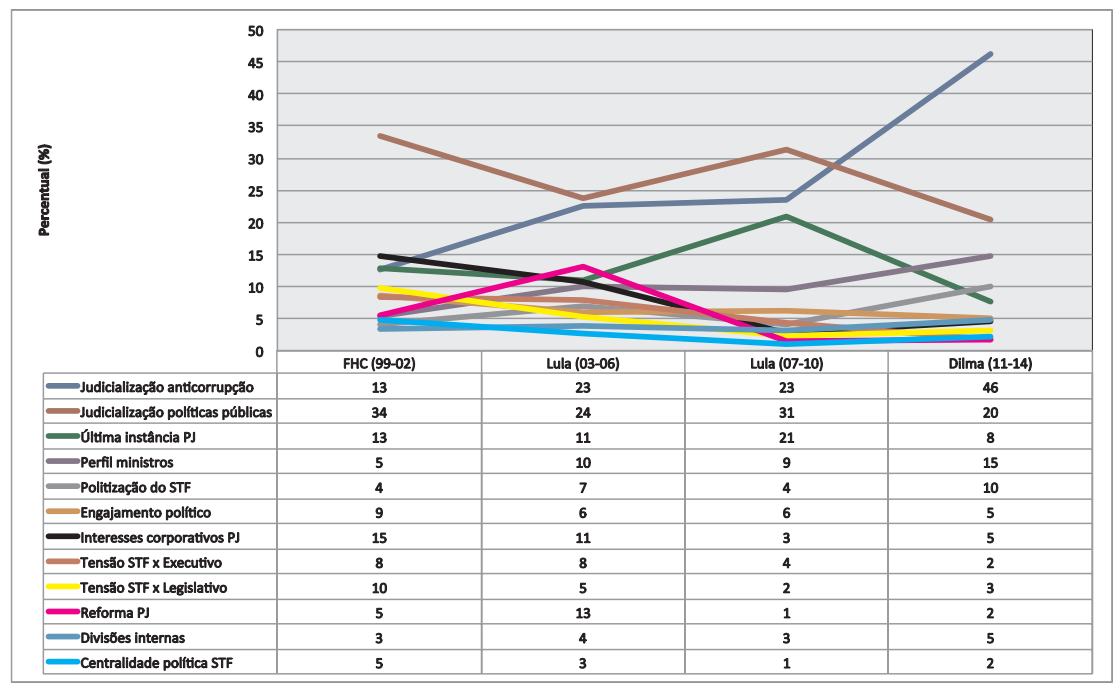

Base: FHC (99-02): 784 notícias; Lula (03-06): 962 notícias; Lula (07-10): 2. 481; Dilma (11-14): 2.044 notícias. 
tivos, que apresenta uma leitura mais positiva sobre a decisão, destacando a centralidade política do tribunal ${ }^{12}$.

O segundo assunto mais recorrente na cobertura do Supremo pela FSP nesse período foi a defesa de interesses corporativos, remetendo às discussões sobre teto salarial e demais garantias da magistratura $(15 \%$ de incidência no total de notícias entre 1999-2002).

Em terceiro lugar, correspondendo a $13 \%$ das notícias cada, estão a atuação do tribunal como última instância do Poder Judiciário e sua atuação em casos de investigação de autoridades com foro privilegiado. Entre os políticos investigados, os mais citados nas notícias desse período foram os senadores Luiz Estevão (PMDB-DF) e Jader Barbalho (PMDB-PA), o deputado federal José Carlos Martinez (PTB-PR) e o então governador do Amapá, João Capiberibe (PSB). Já nesse período, a mídia chamava atenção para a elevada quantidade de processos de autoridades com foro privilegiado tramitando na Justiça ${ }^{13}$.

Se o problema já era visto como grande no final da década de 1990, ele só veio crescendo desde então. No período seguinte, durante o primeiro governo Lula (2003-2006), embora a judicialização de políticas públicas continue sendo a categoria de maior incidência (correspondendo a $24 \%$ do total de notícias), ela é seguida de perto pela judicialização anticorrupção ( $23 \%$ de incidência), tendo sido muito frequente desde 2005 a manchete "escândalo do Mensalão". Nesse período foi bastante noticiada também a Operação Sanguessuga, investigando esquema de compra superfaturada de ambulâncias com verba federal, envolvendo 57 congressistas.

No segundo período ganhou destaque, ainda, o tema da reforma do Judiciário, por conta das discussões e aprovação da Emenda Constitucional n. 45 , sendo o terceiro tema de maior recorrência na cobertura do STF entre 2003 e 2006.

Na discussão sobre a reforma do Judiciário, foi bastante noticiado o debate do controle externo desse poder, e com a aprovação da reforma, a criação do Conselho Nacional de Justiça (CNJ) sofreu diversos questionamentos de setores da magistratura, sendo que a Associação dos Magistrados Brasileiros (AMB) ingressou no STF com uma ação direta de inconstitucionalidade (ADI 3.367), alegando afronta ao princípio constitucional da separação dos poderes. Essa ação esteve com frequência nas notícias, sendo que na cobertura do julgamento houve destaque 
também para as divisões internas de posicionamento entre os minis$\operatorname{tros}^{14}$.

Ainda nesse segundo período, tem destaque a cobertura do perfil dos ministros do STF, por conta das nomeações realizadas por Lula. Entre 2003 e 2006 tomaram posse no STF seis novos ministros: Antonio Cezar Peluso, Carlos Ayres de Britto, Joaquim Benedito Barbosa Gomes, Eros Roberto Grau, Ricardo Lewandowski e Cármen Lúcia Antunes.

Mas a cobertura sobre o perfil dos ministros foi frequente, também, na troca de presidências do STF e quando houve decisões consideradas polêmicas. Em 2004, por exemplo, quando o ministro Marco Aurélio concedeu uma liminar (na ADPF 54) autorizando a interrupção de gravidez no caso de anencefalia, foram diversas as notícias tratando do seu perfil de atuação ${ }^{15}$.

As tensões entre o STF e os poderes Executivo e Legislativo foram mais frequentes nesses dois primeiros períodos. Entre 1999 e 2002 os conflitos com o Legislativo foram mais expressivos $(10 \%$ do total de notícias), devido, sobretudo, à visão de interferência do STF nas diversas CPIs em andamento no Congresso (do Judiciário, dos bancos, do narcotráfico), havendo, inclusive, descumprimento de liminares concedidas pelo STF.

O então presidente do Congresso Nacional, Antonio Carlos Magalhães [ACM] (PFL-BA), justificou o não cumprimento de uma liminar afirmando que "Esse Poder não vai se curvar diante das decisões errôneas como essas que suspenderam os trabalhos da CPI do Narcotráfico" ("CPI descumpre liminar do Supremo", FSP, 16/12/1999). Foram recorrentes também, nesse período, críticas às declarações de ministros à mídia, como a fala de ACM de que "Alguns ministros agem como políticos e estão todos os dias nos jornais, falando o que não devem" (“ACM critica STF por exposição na mídia", FSP, 28/10/1999).

Já com o Executivo, durante o governo FHC, a tensão se deveu às críticas do tribunal ao excesso de edição de medidas provisórias, com o ministro Sepúlveda Pertence afirmando que "uma das funções das medidas provisórias agora é modificar decisões do Supremo" ("STF critica o número de medidas provisórias", FSP, 7/9/2000). E também em decorrência das declarações do então advogado-geral da União, Gilmar Ferreira Mendes, criticando o Judiciário ${ }^{16}$. 
Durante o segundo período, no primeiro governo Lula (2003-2006), a tensão foi maior com o Executivo (8\% do total de notícias), sobretudo devido à reforma do Judiciário, tendo sido muito noticiado o episódio em que, ao defender o controle externo do Judiciário, Lula, então presidente da República, declarou a necessidade de "abrir a 'caixa-preta' de um Poder que muitas vezes se sente intocável" ("Lula critica 'caixa-preta' do Judiciário e defende controle", FSP, 23/03/2003).

No segundo governo Lula, terceiro período em análise (2007-2010), a judicialização de políticas públicas volta a ter maior destaque, correspondendo a $31 \%$ de todas as notícias sobre o STF no período, com a judicialização anticorrupção mantendo a mesma incidência anterior (23\% das notícias), sendo o segundo assunto mais recorrente.

Nesse período houve uma série de decisões do STF que ganharam destaque. Na seara da competição política, o tribunal declarou a inconstitucionalidade de dispositivos da Lei 9.096/95 (Lei dos Partidos Políticos), que instituíam a chamada "cláusula de barreira" (ADI 1.351 e ADI 1.354), e declarou a constitucionalidade da Resolução 22.610/07, do Tribunal Superior Eleitoral, que disciplinou o processo de perda de mandato eletivo por infidelidade partidária (ADI 3.999 e ADI 4.086), além de iniciar o julgamento da lei da ficha limpa. No âmbito da regulação da sociedade civil, permitiu a pesquisa e a terapia com células-tronco embrionárias humanas, declarando a constitucionalidade do artigo 5을 Lei 11.1050/05 (ADI 3.510), e reconheceu a constitucionalidade das cotas raciais para negros e indígenas na universidade (ADPF 186).

Outras decisões muito noticiadas nesse terceiro período foram a da Petição 3.388, questionando a demarcação da reserva indígena Raposa Serra do Sol (RR), a revogação da lei de imprensa (ADPF 130), o julgamento da revisão da Lei da Anistia (ADPF 153), no qual, por 7 votos a 2, o tribunal decidiu arquivar a ação, e a decisão sobre o direito de greve do funcionalismo público (Mandato de Injunção [MI] 670, MI 708 e MI 712), na qual o tribunal declarou, por unanimidade, a omissão legislativa quanto ao dever constitucional em editar lei que regulamente o exercício do direito de greve no setor público e, por maioria, a aplicação da lei de greve vigente no setor privado, vencidos parcialmente os ministros Ricardo Lewandowski, Joaquim Barbosa e Marco Aurélio.

Essa série de decisões provocou tanto elogios quanto críticas à atuação doSTF, prevalecendo a visão da politização do tribunal, que estaria ex- 
trapolando suas funções, e motivando respostas por parte dos minis$\operatorname{tros}^{17}$.

Entre 2007 e 2010, a cobertura do Supremo Tribunal Federal como última instância do Poder Judiciário ficou em terceiro lugar, correspondendo a $21 \%$ das notícias. Essa alta incidência deve-se tanto à cobertura do julgamento de habeas corpus a investigados em operações da Polícia Federal (Anaconda, Jaleco Branco, Hurricane, Satiagraha, Telhado de Vidro, Navalha etc.), como aos banqueiros Daniel Dantas e Salvatore Cacciola, por exemplo, quanto ao julgamento e decisão da extradição do italiano Cesare Battisti (EXT 1.085).

Já no quarto período, durante o primeiro governo Dilma (2011-2014), a judicialização anticorrupção disparou em virtude do julgamento do Mensalão, das prisões de condenados no desfecho desse processo e do julgamento dos embargos infringentes. É preciso levar em conta também que, nesse momento, o país assistiu às primeiras prisões de políticos condenados pelo STF desde a redemocratização, levando a uma cobertura intensa, em decorrência da novidade desses processos ${ }^{18}$.

Nesse período, notícias sobre o perfil dos ministros aumentaram significativamente, sendo o terceiro assunto de maior recorrência na cobertura do STF. O foco dessa cobertura esteve em posicionar o leitor sobre quem são os ministros e como eles votam. Logo em 2011, a sucessão da ministra Ellen Gracie reacendeu o debate sobre o processo de nomeação de ministros e a preocupação de ter um tribunal nomeado majoritariamente por governos petistas - a nomeação de Rosa Weber, primeira indicação da presidente Dilma, marcou a décima indicação do PT ao tribunal.

Durante os dois governos Lula, não foram raros os artigos publicados na FSP que transpareciam apreensão em decorrência do quantitativo de nomeações do PT ao STF, demonstrando receio de que esses ministros seriam entusiastas de projetos políticos e da ideologia do governo que os nomeou e atuariam em defesa desse governo no tribunal. Mas essa preocupação também existiu em administrações anteriores.

Na rápida administração Collor, por exemplo, muito se aventou que Marco Aurélio, Carlos Velloso e Ilmar Galvão atuariam como protetores dos interesses do governo Collor no tribunal, noticiando-se, quando interrompiam julgamentos em questões de interesse do governo com pedidos de vistas, que atuavam pela retirada de casos polêmicos 
da pauta de votação (ver Oliveira, 2004). Também no governo FHC, falou-se muito da "bancada governista do Supremo", em referência aos ministros Nelson Jobim, Ellen Gracie e Gilmar Mendes, que votariam no tribunal favoravelmente às políticas de interesse do governo.

Entre as notícias publicadas no primeiro período (1999-2002), que fazem referência ao slogan "bancada governista no STF", temos, por exemplo, as que tratam da sabatina de Gilmar Mendes e de como ele teria reagido ao ser questionado pelo então senador Jefferson Peres (PDT-AM), se comporia essa bancada: “Tenho pago um preço alto justamente por ser independente, por não me curvar a interesses corporativos. Eu nunca conspurcaria uma biografia construída com tanto esforço" ("Comissão do Senado aprova indicação de Mendes ao STF", FSP, 16/5/2002).

Mas uma vez que os governos do PT nomearam mais ministros, a incidência dessa preocupação foi maior, ganhando em escala. Logo nas primeiras nomeações feitas por Lula a discussão voltou à tona ${ }^{19}$. E permaneceu em voga até o início do julgamento do Mensalão, com o argumento de preocupação pelo PT ter nomeado a maioria dos ministros do tribunal responsável pelo julgamento do caso, preocupação que foi se dissipando à medida que esses ministros votaram e concluiu-se o pro$\operatorname{cesso}^{20}$.

Entre os anos de 2011 e 2014, a crítica da politização do STF atingiu seu ápice, sendo o quarto principal assunto na cobertura do tribunal. A intervenção em uma série de assuntos de relevo na política nacional fez com que a crítica da politização superasse o elogio da centralidade política do tribunal, sendo frequentes, no período, a leitura de usurpação de poder, o questionamento da hipertrofia do Judiciário, e, nas críticas mais severas, chegou-se a falar de "golpe branco"21.

Nesse contexto, a cobertura das tensões internas também se tornou mais expressiva, aparecendo em 5\% do total de notícias sobre o STF. Referências às trocas de críticas entre ministros durante o julgamento do Mensalão foram recorrentes, com o ministro Joaquim Barbosa sendo um dos personagens principais nessas tensões. Ganharam destaque na Folha suas críticas ao ministro Cezar Peluso e sua gestão à frente do STF, "As pessoas guardarão a imagem de um presidente do STF conservador, imperial, tirânico, que não hesitava em violar as normas quando se tratava de impor à força a sua vontade" ("'Desleal e caipira, Peluso manipulou julgamentos do STF', diz Barbosa", FSP, 
20/4/2012). E também a troca de críticas e divisões entre Barbosa, relator da ação do Mensalão, e Lewandowski, revisor; e ainda os "desaforos trocados" entre o ministro Barbosa e o ministro Gilmar Mendes ${ }^{22}$.

A partir da análise do enquadramento temático, notamos que predominou, ao longo de todo o período, a construção e divulgação de uma imagem eminentemente política doSTF. Contabilizando as referências aos aspectos políticos e jurídicos do tribunal, vemos que em $65 \%$ de todas as notícias houve destaque para aspectos políticos da atuação do tribunal e em $56 \%$ delas houve referências a sua atuação técnicojurídica.

\section{Seletividade da cobertura midiática sobre o STF}

As notícias classificadas na dimensão de ações, na categoria "judicialização de políticas públicas", receberam a especificação do assunto em questão, ou seja, qual a temática da política sendo judicializada. Para essa classificação, seguimos Oliveira (2016), tomando como parâmetro de comparação a movimentação na agenda decisória do STF em controle concentrado de constitucionalidade.

É importante observar que utilizamos os dados de Oliveira (2016) apenas como um parâmetro, com a ressalva de que essa comparação não pode ser feita de forma direta, pois os dados da autora referem-se apenas às ADIs decididas pelo STF no período, enquanto as notícias incorporam outros tipos processuais de controle de constitucionalidade, como ADPFs e ADC, e não apenas os casos decididos, mas também os casos em andamento no tribunal. Embora não tratem exatamente do mesmo universo, os dados decisórios podem ser considerados uma boa referência dos temas na pauta de controle de constitucionalidade no $\mathrm{STF}^{23}$.

No período em análise, e conforme pode ser visto no Gráfico 5, o tema mais frequente na pauta decisória do STF foi agentes públicos, que se refere à regulação das carreiras do serviço público, incluindo a criação e organização de carreiras, a regulamentação de concursos públicos, remuneração e outras prerrogativas. Embora tenha sido o tema mais decidido, esteve em terceiro lugar na cobertura jornalística.

Em segundo lugar, os temas mais frequentes na pauta do tribunal foram a regulação da sociedade civil e a administração pública (15\% de incidência cada). Regulação da sociedade civil refere-se aos assuntos 
Gráfico 5

Temáticas da judicialização da política no STF e na cobertura da FSP, de acordo com período (governo) $(\%)$

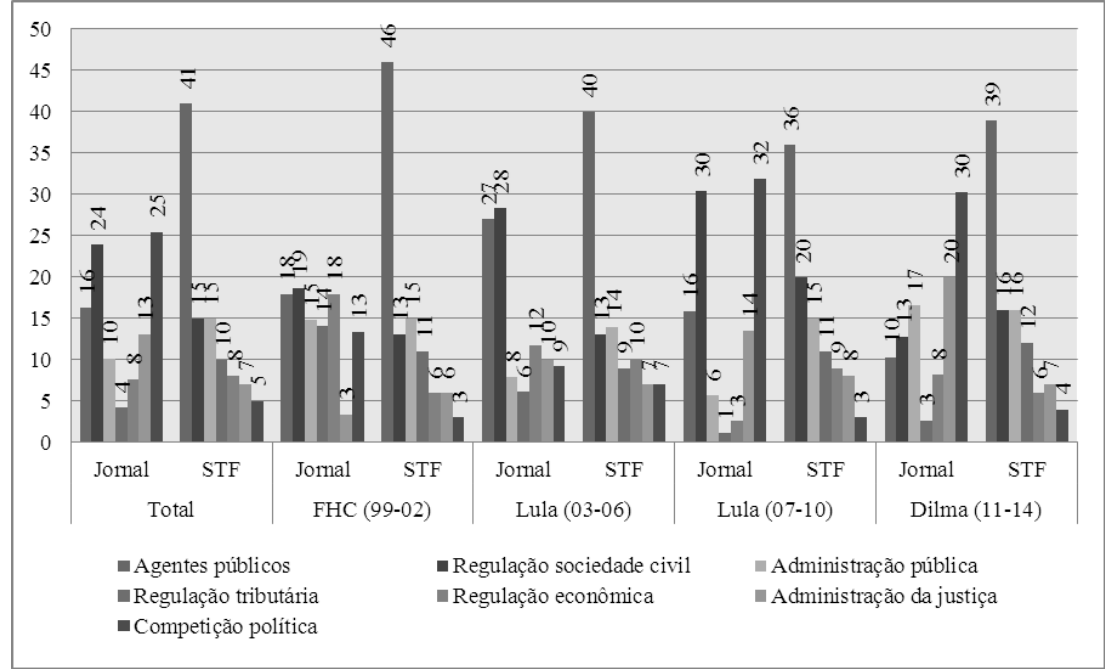

Base jornal (notícias): FHC (99-02): 784; Lula (03-06): 962; Lula (07-10): 2. 481; Dilma (11-14): 2.044. Base STF (decisões ADI): FHC (99-02): 706, Lula (03-06): 845, Lula (07-10): 493, Dilma (11-14): 254.

de maior impacto na sociedade, tratando da agenda de direitos civis, sociais e coletivos. Já a administração pública refere-se à regulamentação das finanças públicas e da política orçamentária, a criação e delimitação de municípios, licitações e concessões de serviços públicos e à separação de poderes. A regulação da sociedade civil é o segundo tema de maior cobertura na FSP, correspondendo a $24 \%$ do total de notícias sobre judicialização da política, e a temática da administração pública, o quinto, com 10\% das notícias. Notamos, assim, uma sobrevalorização da temática da sociedade civil e uma subvalorização dos demais temas da administração pública.

A política tributária foi o terceiro assunto mais frequente na pauta do controle concentrado no STF, referindo-se à discussão de taxas e impostos, como Imposto sobre Circulação de Mercadorias e Prestação de Serviços (ICMS), Contribuição para o Financiamento da Seguridade Social (Cofins) etc. Na cobertura da Folha, é o tema menos incidente, correspondendo a apenas $4 \%$ do total de notícias sobre judicialização de políticas públicas.

Em quarto lugar no STF, esteve a judicialização da política econômica (incluindo os temas da política salarial, política comercial, privatiza- 
ção e planos econômicos), correspondendo a $8 \%$ do total de ações e $8 \%$ do total de notícias, sendo o sexto tema mais noticiado nessa categoria.

Em quinto lugar na pauta do STF, temos o tema da administração da justiça (referindo-se à discussão sobre cartórios, custas, direito processual, segurança pública e precatórios), com 7\% do total de ações. Na cobertura da FSP esse tema recebeu mais atenção, ficando em quarto lugar, com $13 \%$ das notícias.

E, por fim, a regulação da competição política é o tema de menor expressividade na pauta do STF, correspondendo a 5\% do total de ações no período. Já na Folha, foi o principal assunto noticiado, representando $25 \%$ do total de notícias sobre judicialização das políticas públicas.

Notamos que durante o segundo governo FHC (1999-2002) houve um maior equilíbrio da FSP em noticiar as temáticas, com destaque para regulação da sociedade civil e regulação econômica. Já no primeiro governo Lula, a FSP deu maior destaque ao tema da sociedade civil e ao funcionalismo público. Nos últimos dois períodos, segundo governo Lula e primeiro governo Dilma, a competição política disparou, com a regulação econômica e tributária perdendo espaço na cobertura.

Em todo o período, o STF decidiu mais sobre políticas públicas relativas ao funcionalismo público do que a cobertura jornalística apontou. A FSP priorizou noticiar a judicialização da temática de direitos sociais, civis e coletivos e a competição política, havendo uma discrepância entre o que o tribunal decide e o que é noticiado.

Em geral, a análise da cobertura da FSP sobre o STF mostra que houve pouca rejeição ao papel político desempenhado pelo tribunal, sobretudo em decisões referentes às políticas públicas. A Folha cobriu praticamente com a mesma intensidade decisões acerca da temática de direitos (sociais, civis e políticos) e da competição política, sendo que, quando olhamos para a agenda decisória do STF no período, o tribunal decidiu quase três vezes mais sobre os direitos dos servidores públicos do que sobre direitos dos cidadãos em geral, num claro recorte midiático mais favorável à instituição aos olhos da opinião pública.

\section{Perfil ideológico - técnico $\mathrm{x}$ político}

As notícias classificadas em facções, na categoria perfil dos ministros, foram analisadas em busca do uso de sinais linguísticos que remetes- 
sem à caracterização dos ministros e de suas decisões como técnico(a)s ou político(a)s ${ }^{24}$.

Para isso, contabilizamos a quantidade de termos presentes em cada notícia que caracterizassem um perfil ideológico mais técnico (termos: técnico, jurídico, conservador, restritivo, apolítico, corporativista, legalista, formalista, imparcial) e um perfil ideológico mais político (termos: político, progressista, ativista, liberal, independente, protagonista, polêmico). E calculamos a média de termos por notícia em cada perfil, para cada período em análise. Notamos que, em todos os períodos, predominam termos políticos. Mas se no primeiro período a distância entre a frequência média de termos técnicos e políticos é pequena, ela cresce nos demais períodos (Ver Gráfico 6).

No primeiro período em análise, o segundo governo FHC (1999-2002), duas nomeações foram feitas ao STF, Ellen Gracie e Gilmar Mendes. Ambos ministros foram classificados como conservadores pela cobertura da Folha, a partir de análises feitas com base em suas trajetórias pregressas. Ellen Gracie sucedeu o ministro Octavio Gallotti, tido como pertencente à linha mais conservadora do STF. Gilmar Mendes foi nomeado para a vaga de Néri da Silveira, que, segundo a FSP, "Inicialmente integrou a corrente mais conservadora do STF", mas "nos últimos anos, surpreendeu os colegas com votos favoráveis à oposição". ("FHC deve indicar Gilmar Mendes ao STF", FSP, 25/4/2002). Embora

\section{Gráfico 6}

Volume da cobertura do perfil ideológico (média de termos por notícia), de acordo com período (governo)

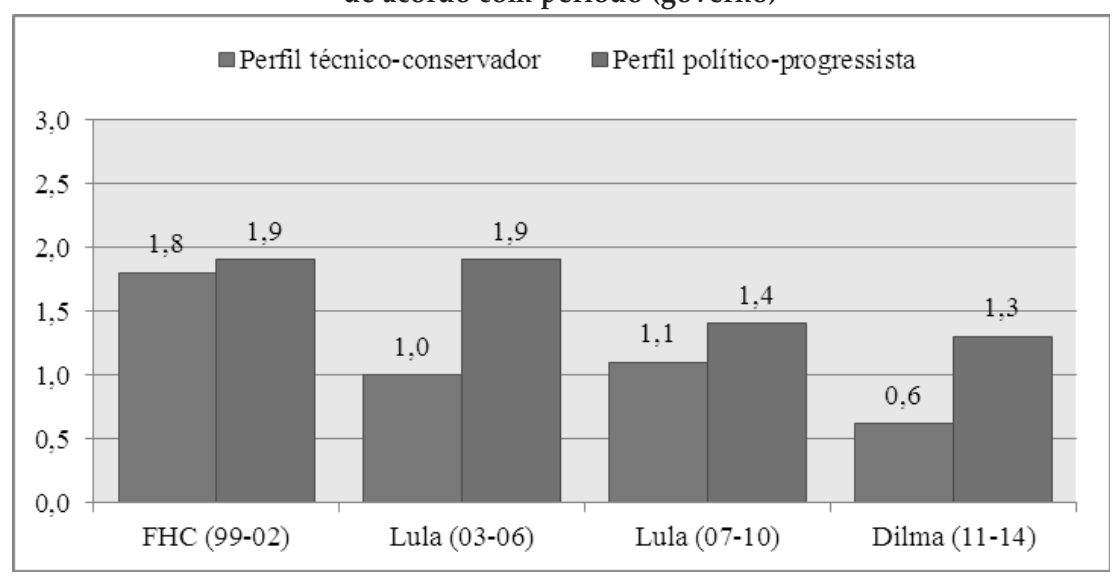

Base de notícias: (FHC 99-02): 42; (Lula 03-06): 97; (Lula 07-10), 234; (Dilma 11-14): 302. 
o ministro Gilmar Mendes tenha sido classificado com perfil conservador, frequentemente foi atribuído a ele o rótulo de político, em virtude de sua trajetória pregressa no governo FHC, como advogado-geral da União.

Nesse período, aparecem classificações referentes ao núcleo mais progressista do STF, composto pelos ministros Sepúlveda Pertence, Carlos Velloso, Marco Aurélio de Mello, Maurício Corrêa, e ao núcleo tido como mais técnico, composto pelos ministros Moreira Alves, Sidney Sanches e Celso de Mello - os dois primeiros vistos como mais conservadores e o último como mais progressista e liberal, sobretudo em questões penais. Nelson Jobim e Ilmar Galvão aparecem no grupo classificado como conservador, mas Jobim recebeu com frequência o rótulo de "perfil político", por sua trajetória política antes do ingresso no tribunal ${ }^{25}$.

No segundo período, de 2003 a 2006, foram nomeados seis novos ministros ao STF. Joaquim Barbosa ocupou a vaga decorrente da aposentadoria do ministro Moreira Alves: um ministro tido no espectro mais progressista para substituir um ministro mais conservador. Polêmico, foi um adjetivo bastante utilizado para descrever Barbosa, sobretudo durante o julgamento do Mensalão.

Cezar Peluso foi a segunda nomeação de Lula e ocupou a vaga decorrente da aposentadoria do ministro Sydney Sanches: um magistrado técnico e conservador para substituir outro com o mesmo perfil, de acordo com cobertura da Folha.

Ayres Britto, de perfil mais progressista, foi nomeado para suceder o ministro Ilmar Galvão, mais conservador. Quando Britto assumiu a presidência do STF, o jornal publicou várias notícias sobre seu perfil, ressaltando que Britto foi um dos únicos ministros a se posicionar favoravelmente às "inovações controversas recentes no plenário": a favor da validade da lei da ficha limpa para as eleições de 2012, do aborto de fetos anencéfalos, da liberação das chamadas "marchas da maconha", do reconhecimento da união homoafetiva e pela revisão da Lei da Anistia.

O quarto ministro nomeado por Lula, considerado de perfil mais técnico, foi Eros Grau, na vaga decorrente da aposentadoria do ministro Maurício Corrêa. O quinto ministro nomeado foi Ricardo Lewandowski, em substituição ao ministro Carlos Velloso. 
Lewandowski é tido como um ministro de perfil mais técnico e conservador. Na cobertura que a FSP fez sobre o caso do aborto de fetos anencéfalos, foi destacado que ele votou contrariamente à liberação.

A sexta nomeação realizada por Lula foi a da ministra Cármen Lúcia, em vaga decorrente da aposentadoria do ministro Nelson Jobim. Cármen Lúcia é tida como uma ministra de perfil liberal e também identificada com posições mais progressistas, tendo votado a favor da permissão para as marchas da maconha, da cota para negros em universidades, da união homoafetiva e do aborto de fetos anencéfalos.

Em artigo publicado na Folha em 2013, o colunista Schwartsman classificou a ministra Cármen Lucia, ao lado de Rosa Weber e Celso de Mello, como "swing justices" (ministros-pêndulo), afirmando que podem alinhar-se "ora a um núcleo ideológico da corte, ora a outro, determinando as maiorias que decidem os casos" ("As cabeças dos juízes", FSP, 13/9/2013).

No segundo governo Lula, o terceiro período em análise (2007-2010), foram nomeados os ministros Menezes Direito, em decorrência da aposentadoria de Sepúlveda Pertence, e Dias Toffoli, para substituir Direito, que faleceu em setembro de 2009. Direito sempre foi retratado como um ministro conservador e técnico. Toffoli votou mais alinhado à ala conservadora, mas recebeu com frequência o rótulo de político, devido a sua trajetória pregressa e à proximidade com o PT.

Ganhou destaque também no período, a cobertura da presidência de Gilmar Mendes, tida por muitos como conservadora, com o próprio ministro sendo classificado em uma notícia como "uma das mais contundentes vozes da direita conservadora brasileira". Ao final de sua gestão à frente do STF e do CNJ, o jornal publicou declarações de Mendes afirmando que sua gestão não poderia ser considerada conservadora: "Editamos a súmula das algemas, evitando assim abusos policiais notórios contra todos. (...) No CNJ, os mutirões carcerários beneficiaram 20 mil pessoas. Na falta da assistência judiciária, nós lançamos a advocacia voluntária. Isso é política conservadora, de direita?" ("Na despedida do cargo, presidente do STF nega que sua gestão foi conservadora", FSP, 16/4/2010).

O quarto período, de 2011-2014, foi marcado pela nomeação de quatro ministros e pela decisão da AP 470. Luiz Fux, primeiro nomeado de Dilma, vem da carreira da magistratura e foi caracterizado como mais 
conservador. Rosa Weber, também da carreira da magistratura, é vista como uma juíza com perfil mais progressista. Ganhou destaque seu voto na ADI 4.638, na qual o STF decidiu pela constitucionalidade do Conselho Nacional de Justiça (CNJ) investigar e punir juízes e servidores do Judiciário. A decisão dividiu a corte, posicionando na corrente minoritária os ministros Marco Aurélio (relator), Lewandowski, Fux, Peluso e Mello, favoráveis à limitação dos poderes investigatórios do CNJ, e na corrente majoritária os ministros Mendes, Britto, Barbosa, Cármen Lúcia, Weber e Toffoli, contrários à limitação.

Teori Zavascki, terceiro nomeado por Dilma, foi caracterizado pelo jornal como um ministro de perfil técnico. E o quarto nomeado, Roberto Barroso, retratado pela FSP como um ministro liberal.

Muitas notícias nesse período chamaram atenção para o delineamento de um STF mais liberal com as nomeações feitas por Dilma. E durante o julgamento do Mensalão foram diversas as notícias cobrindo o voto de cada um dos ministros, com atenção especial aos nomeados pelos governos do PT.

A Folha fez uma cobertura intensiva, e foram diversas as notícias trazendo falas de advogados dos acusados, e mesmo de membros do governo, classificando o processo como político, e falas de ministros defendendo o processo como técnico.

Exemplo disso está em notícia na qual o relator do caso, ministro Barbosa, afirma que são afrontas ao tribunal as acusações de réus de que houve julgamento político ("Condenados no mensalão, Dirceu e mais quatro entregam passaportes ao STF", FSP, 9/11/2012). E do então presidente do tribunal, ministro Britto, afirmando que o julgamento seria técnico, apesar das pressões políticas, declarando que "Todos nós temos essa compreensão, que corresponde a um dever de ofício, de que por mais intensa e densa que seja a ambiência política de um processo, o julgamento só pode ser técnico, em cima das provas dos autos, objetivamente" ("Presidente do STF diz que julgamento do mensalão acaba em agosto", FSP, 20/6/2012).

A partir do julgamento do Mensalão é possível observar uma maior atenção da FSP ao perfil dos ministros e o aumento da incidência da crítica ao seu individualismo, como em editorial publicado no início de 2014 afirmando que "Enquanto instituição, o Supremo foi em boa medida ofuscado pelos indivíduos que o compõem. Manteve-se o proces- 
so, iniciado em 2012 com a análise do mensalão, de transformação dos ministros em celebridades, elogiados ou criticados por suas opiniões pessoais e vigiados no cotidiano" ("STF em pauta", FSP, 6/1/2014).

\section{CONSIDERAÇÕES FINAIS}

Neste artigo discutimos a visibilidade do STF, a partir da análise sistemática da cobertura do jornal Folha de S. Paulo sobre o tribunal, buscando responder sobre o que a opinião pública fala quando o assunto é o STF e como a mídia tem retratado a performance do tribunal.

Nosso objetivo foi verificar o tipo de cobertura predominante (política ou jurídica), os temas de maior recorrência no enquadramento da instituição e os fatores que determinam essa cobertura. Trabalhamos a partir do modelo proposto por Johnson e Socker (2012) para a Suprema Corte norte-americana, considerando três conjuntos de fatores: ações (os casos que a corte decide), facções (a dinâmica interna no processo decisório) e interações (como a corte se insere no sistema político mais amplo).

No período analisado (1999-2014), o que moveu a cobertura do Supremo Tribunal Federal foram as ações: $70 \%$ de todas as notícias traziam referência a um caso específico na agenda decisória do tribunal. Nos primeiros dois períodos analisados houve equilíbrio no enfoque entre ações e interações, mas a partir de 2007, ano em que foi protocolada a ação do Mensalão, a cobertura na dimensão das ações disparou e seguiu na liderança absoluta até 2014, último ano incluído na pesquisa.

Notamos uma ênfase excessiva nas ações de judicialização anticorrupção e no julgamento de autoridades políticas, e um enfoque no poder individual de cada ministro, com o crescimento de notícias acerca do seu perfil (quem são e como votam), evidenciando uma construção midiática que exacerba a personalização da instituição em seus ministros.

Observamos, ainda, um descompasso entre as questões de interesse midiático e as temáticas que o STF decidiu: decisões sobre direitos (sociais, civis e coletivos) e sobre a competição política apareceram com frequência maior do que sua proporção no volume de trabalho do Supremo Tribunal Federal.

No que se refere à avaliação da performance do tribunal, ou seja, ao papel que o STF vem desempenhando no cenário político brasileiro, é 
destacada a cobertura do protagonismo político da instituição, havendo maior incidência da chave da politização (7\% do total de notícias) em comparação à chave da centralidade do STF, ocupando vácuo de poder ( $2 \%$ do total de notícias).

Notamos, também, um baixo reforço dos símbolos tradicionais de legitimidade que contribuem para distanciar as cortes dos demais poderes políticos - apenas $1 \%$ do total de notícias afirma o discurso de imparcialidade e o perfil apolítico da instituição. A cobertura priorizou o perfil individual dos ministros ( $11 \%$ do total de notícias) e seu engajamento político ( $6 \%$ do total de notícias), dando destaque também às tensões e divisões internas no tribunal ( $4 \%$ do total de notícias).

Podemos concluir, assim, que o jornal Folha de S. Paulo construiu uma imagem eminentemente política do Supremo Tribunal Federal entre os anos de 1999 e 2014.

(Recebido em 19/12/2016)

(Aprovado em 20/12/2017) 


\section{NOTAS}

1. Sobre o conceito de judicialização da política ver Castro (1997); Werneck Vianna et al. (1999); Maciel, Koerner (2002), Carvalho (2004), Arantes (2005) e Veronese (2009). Sobre o conceito de ativismo judicial ver Veríssimo (2008), Arguelhes, Oliveira, Ribeiro (2012) e Koerner (2013).

2. Falcão e Oliveira (2013: 447-448) afirmam que, embora a maioria dos brasileiros declare conhecer ou ter ouvido falar sobre o STF (69\%), apenas uma minoria de fato tem ideia do que o Supremo faz e de qual seu papel no sistema político brasileiro ( $30 \%$ dos entrevistados souberam dizer pelo menos uma função do tribunal).

3. Essa escolha se baseia no reconhecido grau de desenvolvimento dessa área nos Estados Unidos (Miljan, 2014).

4. Os autores especificam as listas iniciais de termos com sentido legal e com sentido político que utilizam na análise. Entre os termos que indicariam cobertura jurídica destacamos: amicus curiae, apelante, ônus da prova, devido processo, habeas corpus, jurisprudência, precedente etc. Entre os termos que indicariam sentido político, destacamos: tendencioso, extremista, ideológico, parcial, partidário, politizado etc.

5. Dados da pesquisa Latin American Public Opinion Project (Vanderbilt University), mostram uma maior conscientização sobre o STF e uma melhor avaliação da instituição entre os anos de 2006 e 2012: ao responderem até que ponto confiavam no STF, 5\% dos brasileiros não emitiram opinião por desconhecer a corte em 2006, e 37\% afirmaram confiar no tribunal, atribuindo nota acima de 4 na escala que vai de 1 a 7 . Já em 2012, somente 1\% não emitiu opinião, e 43\% afirmaram confiar (Vanderbilt University, s.d.). Outra pesquisa que permite ver essa tendência é o ICJBrasil, da FGV. Entre junho e julho de 2016, a pesquisa indagou à amostra de brasileiros entrevistados se estavam acompanhando a participação do Supremo Tribunal Federal no caso do impeachment de Dilma Rousseff, e 77\% responderam afirmativamente (Fundação Getúlio Vargas, s.d.).

6. Exemplo dessa afirmação está em artigo de opinião escrito por Luiz Werneck Vianna publicado no jornal O Estado de S. Paulo, no qual analisa as decisões do STF referentes aos ritos que deveriam ser seguidos na tramitação do processo de impeachment da então presidente Dilma Rousseff, afirmando que "Finda a votação, um país perplexo pôde constatar que mais um passo tinha sido dado em direção a um governo de juízes". (Werneck Vianna, 2016). Outro exemplo do uso da expressão está em notícia publicada pelo El País, “Ex-premiê espanhol Felipe González alerta sobre um possível 'governo dos juízes' no Brasil" (Betim, 2016).

7. A restrição da pesquisa a um único veículo atende a uma necessidade operacional: embora a coleta de dados tenha sido automatizada, e análises exploratórias tenham sido feitas via técnica de mineração de texto com auxílio do R (contagem de termos e expressões), a análise de enquadramento temático final das notícias foi realizada pela autora via leitura e classificação manual das notícias. Considerando que diferentes veículos possuem linha editorial e orientação política distintas, os dados apresentados no artigo guardam essa limitação. Mas, uma vez que nosso interesse está mais na visibilidade do tribunal do que na orientação política dos jornais, a FSP pode ser considerada um "termômetro" válido da inserção do STF no cenário público nacional no período analisado. 
8. As buscas foram feitas ano a ano, tanto no jornal impresso quanto no online, no endereço: http://search.folha.uol.com.br/?q=. O levantamento se deu a partir de uma rotina de webscrapping utilizando o software $\mathrm{R}$, entre outubro de 2014 e março de 2015.

9. Exemplo de notícia classificada nessa categoria é "Ministro do STF critica 'Lei da Mordaça'” (FSP, 17/12/1999): “O ministro do STF Celso de Mello afirmou ontem que é inconstitucional o projeto de lei que proíbe juízes, membros do Ministério Público e delegados de polícia de dar informações sobre casos em investigação. (...) ‘Constitui estranho paradoxo impor-se, na vigência de um regime que reclama transparência, a regra do silêncio obsequioso, transformando perigosamente em regra o que deveria revestir-se de excepcionalidade absoluta', disse o ministro."

10. Exemplo de notícia classificada na categoria é "STF rejeita proposta do governo sobre o salário do Judiciário" (FSP, 11/6/2006): "A presidente do STF, ministra Ellen Gracie Northfleet, comunicou anteontem ao governo que considera 'inaceitável' a contraproposta de aumento salarial do Judiciário, o que aumenta o constrangimento político entre os dois Poderes. O Supremo, com apoio dos demais tribunais superiores, exige índices diferenciados de reajuste que somam $\mathrm{R} \$ 5,2$ bilhões a mais por ano na folha de pagamento. A contraproposta feita anteontem a Ellen, e recusada, implicava num total inicial de R \$2,4 bilhões, diluindo o restante nos próximos anos."

11. Exemplo de notícia classificada nessa categoria é "'Ativismo' do STF foi resposta ao esquema do mensalão, diz ministro" (FSP, 12/6/2013): "A crítica de que existe 'ativismo judicial' em assuntos políticos é recorrente. O Supremo afirma que apenas preenche, quando necessário, lacunas deixadas pelo Congresso."

12. “Dizer que a decisão do Supremo, na questão dos proventos de inativos, foi isoladamente política está errado, porque, paradoxalmente, tudo o que o tribunal julga produz resultado político. A sociedade tem o direito de criticar a orientação da mais alta corte do país e até supor que haja decisões consequentes de interesses menos sérios. A história do Supremo mostra o oposto, tornando inaceitável que seus ministros decidam coletivamente, com desprezo pela nobreza de sua missão constitucional. Esse temor o povo não precisa ter" ("STF enquanto órgão político", FSP, 9/10/1999).

13. "Existem pelo menos 14 mil brasileiros recebendo tratamento especial na Justiça. (...) Até quatro meses atrás, no entanto, deputados, senadores, juízes, ministros de Estado e outros mantinham a vantagem, ainda que não estivessem mais nos cargos. No último 25 de agosto, uma decisão unânime do Supremo acabou com essa possibilidade. Foi cancelado o privilégio do foro especial a ex-ministros, ex-deputados e ex-senadores, por exemplo, que tivessem cometido crimes quando estavam na função ("Autoridades brasileiras não são julgadas por juízes de 1ํㅡㅁau", FSP, 3/1/2000).

14. "Por 7 votos contra 4 , foi rejeitada uma ação direta de inconstitucionalidade da AMB (Associação dos Magistrados Brasileiros) contra o Conselho, que deverá ser criado até 6 de junho. (...) O julgamento de ontem, particularmente o voto de Peluso, surpreendeu outros ministros. Sétimo a votar, quando o placar já indicava 5 votos a 1 , Marco Aurélio disse que se confirmava o 'princípio da imprevisibilidade' das decisões judiciais. Carlos Velloso também criticou a mudança de opinião do relator em relação a um voto de fevereiro de 2004" ("Controle externo é constitucional, decide STF", FSP, 14/4/2005). 
15. “Marco Aurélio de Mello é visto no meio jurídico como o mais polêmico dos 11 ministros do STF em razão de decisões individuais como a absolvição em 1996 de um encanador de Minas Gerais que tinha sido condenado por estupro porque manteve relação sexual com uma menina de 12 anos de idade. (...) Ele foi nomeado para o STF em 1990 pelo presidente Fernando Collor, de quem é primo. Desde então também ficou conhecido no meio jurídico como 'o ministro do voto vencido' porque frequentemente tem entendimento diferente do adotado pela maioria dos colegas. Outra característica de Marco Aurélio é a posição 'liberal' em relação ao cumprimento de pena de prisão antes de sentença de condenação definitiva" ("Ministro é visto como o mais polêmico do STF", FSP, 2/7/2004).

16. “Ao defender os interesses do governo, o 'juridiquês' de Mendes incorporou termos como 'manicômio judiciário', na luta pelo fim da greve nas universidades, 'autismo dos juízes', na privatização do Banespa, e 'censura prévia', quando sugeriu que os ministros do Supremo Tribunal Federal não falassem mais em off. (...) O presidente da corte, ministro Marco Aurélio de Mello, diz que o comportamento de Mendes, ao usar a expressão 'manicômio judiciário' , 'ultrapassou os limites do aceitável no vernáculo e no bom relacionamento'. Com isso, avisa Marco Aurélio, 'ele se desgasta e perde como interlocutor' ("Polêmico, Mendes acumula atritos com Poder Judiciário", FSP, 2/12/2001).

17. “'Nós não legislamos. É uma visão míope assentar-se que o Judiciário estaria legislando', afirmou Marco Aurélio, em São Paulo. (...) ‘O Judiciário é um órgão inerte e somente atua mediante provocação e vinculado à legislação existente. A última trincheira é o Judiciário, que não faltará ao povo brasileiro e, quando convocado, se pronunciará sem legislar', afirmou Marco Aurélio" ("Marco Aurélio defende atuação do TSE e diz que Judiciário não legisla", FSP, 26/10/2007).

18. "Consolida-se, aos poucos, a percepção de que os ministros do STF estão dispostos a modificar a imagem da corte perante a população e converter em exceção a regra da impunidade que sempre vigorou para os políticos brasileiros. Há pouco mais de um mês, o STF mandou prender o deputado federal Natan Donadon (ex-PMDB-RO), condenado em 2010 por desvios cometidos nos anos 1990 na Assembleia Legislativa de Rondônia. Foi a primeira ordem de prisão expedida contra parlamentar desde a redemocratização do país. Agora, pela primeira vez na história, o tribunal condenou um senador da República. Ivo Cassol (PP-RO) foi sentenciado a mais de quatro anos de prisão por crimes praticados quando foi prefeito de Rolim de Moura (RO), de 1997 a 2002" (“Um STF diferente", 10/8/2013).

19. "A escolha de um filiado ao PT, o advogado sergipano Carlos Ayres de Britto, vai contra o que defendeu o partido em ocasiões passadas. Os petistas atacaram os três ministros nomeados pelo ex-presidente FHC justamente pela afinidade política. (...) Mendes elogiou ontem as três indicações de Lula, mas acusou o PT de 'satanizar' os indicados de FHC. Quando ele foi indicado, o PT se opôs à nomeação, dizendo que deveria haver quarentena (tempo fora de funções públicas) para cargos como o ocupado por Mendes. 'Agora acabam de escolher um filiado ao PT. Esse critério não vale para eles', disse. Joaquim Barbosa e Antonio Cezar Peluso, presentes à cerimônia no Palácio do Planalto em que foram formalmente indicados para o STF, disseram não temer o rótulo de integrantes da nova bancada governista no Supremo" ("PT criticou indicações 'políticas' de FHC para o STF", FSP, 8/5/2013). 
20. “Com a aposentadoria de Barbosa, a petista indicará seu quinto ministro do STF. Mas não superará o número de escolhas de seu antecessor imediato, Luiz Inácio Lula da Silva: oito. (...) Dilma mudou o perfil de indicações após sua primeira escolha, quando optou por Luiz Fux. (...) No julgamento do mensalão, quando o tribunal condenou 25 pessoas, entre elas a cúpula do PT, Fux foi um dos ministros que mais se alinhou às ideias de Barbosa. Juntos, Lula e Dilma já indicaram 12 ministros ao STF. A conta subirá com a nova substituição. Nem assim petistas ligados ao mensalão se livraram da condenação" ("Dilma deve deixar o anúncio de ministro para depois da Copa", FSP, 31/5/2014).

21. “(...) é inegável que a democracia brasileira vem sendo fustigada pela hipertrofia do papel do Judiciário, em especial do Supremo Tribunal Federal. Há quem chame isto de judicialização da política. Ou quem sabe ensaio de golpe branco em vários níveis da administração" ("O ensaio de golpe branco do STF”, FSP, 13/1/2014).

22. O artigo "O Supremo não é uma ilha", publicado na Folha de S. Paulo em 17/9/2013, ilustra bem essas tensões e divisões internas: “Os desaforos trocados há tempos pelos ministros Gilmar Mendes e Joaquim Barbosa deixaram claro para os leigos que o plenário é também uma arena. Os ataques do mesmo Joaquim Barbosa ao ministro Ricardo Lewandowski mostraram que o plenário é sobretudo uma arena."

23. Fazemos essa afirmação levando em conta que Oliveira (2016) utilizou como parâmetro para sua classificação os trabalhos pioneiros de Werneck Vianna et al. (1999 e 2007), que analisam tanto as ADIs decididas quanto as que se encontravam em tramitação no STF, e a pesquisa de Sundfeld et al. (2010), que consideram outras classes processuais em controle concentrado de constitucionalidade.

24. Utilizamos o termo técnico significando restritivo, implicando um posicionamento mais contido quanto à possibilidade de atuação do STF em questões políticas e uma tendência de evitar considerar as consequências políticas, econômicas e/ou sociais da decisão. Já o termo político foi utilizado com o significado de ativista, implicando uma visão mais ampla da atuação do STF nas questões políticas e uma tendência de considerar as consequências políticas, econômicas e/ou sociais da decisão. Sobre a construção dessas categorias, remetemos a trabalhos anteriores: Oliveira (2011; 2014).

25. “A fama de membro político do STF começou a ser atribuída ao hoje presidente do órgão, Nelson Jobim, desde que ele foi levado por FHC do Ministério da Justiça para o STF, em 1997. Quase um mês após a posse, um pedido de vista seu adiou a decisão sobre uma liminar em ação ajuizada pela oposição. Devido a esse e a outros pedidos de vista, cuja demora interessava a FHC, Jobim ganhou do PT o apelido de 'líder do governo no STF'. (...) Ficou conhecido como o mais político dos 11 membros do STF" ("Presidente é o mais político dos membros do STF", FSP, 13/12/2005). 


\section{REFERÊNCIAS BIBLIOGRÁFICAS}

ARANTES, Rogério Bastos. (2005), "Constitutionalism, the Expansion of Justice and the Judicialization of Politics in Brazil”, in R. Sieder; L. Schjolden; A. Angell (orgs.), The Judicialization of Politics in Latin America". New York, Palgrave MacMillan.

ARGUELHES, Diego W.; OLIVEIRA, Fabiana Luci de; RIBEIRO, Leandro Molhano. (2012), "Ativismo judicial e seus usos na mídia brasileira". Revista Direito, Estado e Sociedade, 40: 34-64.

BETIM, Felipe (2016). “Ex-premiê espanhol Felipe González alerta sobre um possível "governo dos juízes" no Brasil". Disponível em: http://brasil.elpais.com/brasil/2016/03/10/politica/1457646535_690036.html. Acesso em: 28/10/2016.

BIROLI, Flávia; MANTOVANI, Denise. (2014). "A parte que me cabe nesse julgamento: a Folha de S. Paulo na cobertura ao processo do 'mensalão'". Opinião Pública, 20(2): 204-218.

CASTRO, Marcus Faro de. (1997), “O Supremo Tribunal Federal e a judicialização da política". Revista Brasileira de Ciências Sociais, 12(34): 147-155.

CALDEIRA, Gregory; GIBSON, James. (1992). "The etiology of public support for the Supreme Court". American Journal of Political Science, 36(3): 635-64.

CARVALHO, Ernani. (2004). “Em busca da judicialização da política no Brasil: apontamentos para uma nova abordagem". Revista de Sociologia e Politica, 23: 115-126.

DAVIS, Michael H. (1987). "A Government of Judges - An Historical Review". The American Journal of Comparative Law, 35(3): 559-580.

FALCÃO, Joaquim; CERDEIRA, Pablo C.; ARGUELHES, Diego W. (2011). I Relatório Supremo em Números - o Múltiplo Supremo. Rio de Janeiro, FGV. Disponível em: http:/ / hdl.handle.net/10438/10312. Acesso em: 28/11/2016.

FALCÃO, Joaquim; OLIVEIRA, Fabiana Luci de. (2013). “O STF e a agenda pública nacional: de outro desconhecido a supremo protagonista?". Lua Nova, 88: 429-469.

GARAPON, Antoine. (1999). O juiz e a democracia: o guardião das promessas. Rio de Janeiro: Revan.

GIBSON, James; CALDEIRA, Gregory; BAIRD, Vanessa. (1998). “On the Legitimacy of National High Courts". The American Political Science Review, 92(2): 343-358.

HIRSCHL, Ran (2008). "The Judicialization of Mega-Politics and the Rise of Political Courts". Annual Review of Political Science, 11: 93-118.

JOHNSON, Tyler; SOCKER, Erica. (2012). "Actions, Factions, and Interactions: Newsworthy Influences on Supreme Court Coverage". Social Science Quarterly, 93(2): 434-463.

JONES, Ronnel A. (2014). "Media Politicization of the United States Supreme Court". On ati Socio-legal Series [online], 4(4): 613-630.

KOERNER, Andrei. (2013). “Ativismo judicial?: Jurisprudência constitucional e política no STF pós-88". Novos Estudos - Cebrap, 96: 69-85.

MACIEL, Débora Alves; KOERNER, Andrei. (2002). “Sentidos da judicialização da política: duas análises". Lua Nova, 57: 113-133. 
MILJAN, Lydia. (2014). "Supreme Court Coverage in Canada: A Case Study of Media Coverage of the Whatcott Decision". On ati Socio-legal Series [online], 4(4): 709-724.

MIGUEL, Luís Felipe; BIROLI, Flávia (2011). “Meios de comunicação de massa e eleições no Brasil: da influência simples à interação complexa". Revista USP, 90: 74-83.

O'CALLAGHAN, Jerome; DUKES, James. (1992). “Media Coverage of the Supreme Court's Caseload". Journalism Quarterly, 69(1): 195-203.

OLIVEIRA, Fabiana Luci de. (2004). "O Supremo Tribunal Federal no processo de transição democrática: uma análise de conteúdo dos jornais Folha de S. Paulo e O Estado de S. Paulo". Revista de Sociologia e Política, 22: 101-118.

. (2011). Justiça, profissionalismo e política - O STF e o controle de constitucionalidade das leis no Brasil. 1. ed. Rio de Janeiro, Editora FGV.

(2013). “Agenda suprema: interesses em disputa no controle de constitucionalidade das leis no Brasil". Tempo Social, 28(1): 105-133.

. (2014). Supremo Tribunal Federal - a dimensionalidade da votação. In: 38o Encontro Anual da Anpocs, 2014, Caxambu. Anais do 38e Encontro Anual da Anpocs.

; RAMOS, Luciana. (2016), “Conhecer o STF é confiar nele?". Disponível em: jota.info/conhecer-o-stf-e-confiar-nele. Acesso em: 4/11/2016.

SLOTNICK, Elliot. (1992). "Media coverage of Supreme Court decision making: problems and prospects". Judicature, 75(3): 128-142.

SPILL, Rorie; OXLEY, Zoe. (2003). "Philosopher kings or political actors?". Judicature, 87(1): 22-29.

SUNDFELD, Carlos Ari et al. (2010), Controle de constitucionalidade e judicialização: o STF frente a`sociedade e aos Poderes. Belo Horizonte, Faculdade de Filosofia e Ciências Humanas.

VANDERBILT UNIVERSITY. (s.d.) Latin American Public Opinion Project. Disponível em: http:/ / www.vanderbilt.edu/lapop/brazil.php. Acesso em: 4/11/2016.

VERONESE, Alexandre. (2009). “A judicialização da política na América Latina: panorama do debate teórico contemporâneo". Escritos: revista da Casa de Rui Barbosa, 3: 215-265.

VERÍSSIMO, Marcos Paulo. (2008). “A Constituição de 1988, vinte anos depois: suprema corte e ativismo judicial 'a` brasileira'”. Revista Direito GV, 4(2): 407-440.

WERNECK VIANNA, Luiz et al. (1999). A judicialização da política e das relações sociais no Brasil. Rio de Janeiro, Iuperj/Revan.

(2007), “Dezessete anos de judicialização da política". Tempo Social, 2(19): 39-85.

WERNECK VIANNA, Luiz. (2016). “O pontificado laico e a República”. Jornal O Estado de S. Paulo, 03/01/2016. Disponível em: http://opiniao.estadao.com.br/noticias/ geral,o-pontificado-laico-e-a-republica,10000006097. Acesso em: 28/11/2016. 


\section{RESUMO}

Judiciário e Política no Brasil Contemporâneo: Um Retrato do Supremo Tribunal Federal a partir da Cobertura do Jornal Folha de S. Paulo

O objetivo do artigo é discutir a visibilidade do Supremo Tribunal Federal (STF), qualificando-a a partir da cobertura da grande imprensa. Buscamos descrever como o jornal Folha de S. Paulo (FSP) retratou a atuação do Supremo no período de 1999-2014, enfocando o tipo de cobertura predominante (política ou jurídica), os temas de maior recorrência no enquadramento da instituição, e os fatores que determinam a cobertura. Verificamos em que medida essa cobertura acompanha as ações efetivas do tribunal, examinando quais decisões viraram notícia. Para isso, trabalhamos com a análise de conteúdo de 6.271 notícias. A partir desses dados problematizamos a construção da imagem pública do tribunal e a forma pela qual a mídia vem posicionando a instituição no sistema político brasileiro. Concluímos que a FSP construiu uma imagem eminentemente política do STF, com sua cobertura exacerbando a personalização da instituição, o perfil individual dos seus ministros, e enfatizando excessivamente os casos de judicialização anticorrupção.

Palavras-chave: Supremo Tribunal Federal; mídia; enquadramento político; enquadramento jurídico; judicialização anticorrupção

\section{ABSTRACT \\ Politics and the Judiciary in Contemporary Brazil: A Portrait of the Supreme Federal Court Based on its Representation in Folha de São Paulo Newspaper}

The aim of this article is to discuss the visibility of Brazil's Supreme Federal Court (STF) based on its representation in the mass media. To do so, we describe how Folha de São Paulo (FSP) newspaper depicted the court's activities in the period from 1999 to 2014, focusing on the predominant type of coverage (whether political or legal), the subjects most frequently framed in terms of the institution, and the factors determining the representation. We discuss the extent to which the coverage traces the court's activities, examining which rulings were deemed newsworthy by analyzing the contents of 6,271 news items, using the data to problematize the shaping of the public image of the court and the way in which the media come to position the institution in the Brazilian political system. We conclude that the FSP shaped a predominantly political image of the STF, with this representation exacerbating the institution's personalization, the individual profiles of its ministers, and promoting an excessive emphasis on cases of anti-corruption judicialization.

Key words: Brazilian Supreme Federal Court; media; political framework; legal framework; anti-corruption judicialization 


\section{RÉSUMÉ}

La Justice et la Politique dans le Brésil Contemporain: Un Portrait de la Cour Suprême Fédérale à partir de la Couverture qu'en Fait le Quotidien Folha de S. Paulo

Le but de cet article est de débattre de la visibilité de la Cour Suprême Fédérale du Brésil (STF) dans les principaux médias brésiliens. Nous chercherons à décrire de quelle manière le quotidien Folha de S. Paulo (FSP) a rendu compte des actions de cette Cour suprême entre 1999 et 2014. Nous nous intéresserons à cette fin au type de couverture prédominant (politique ou juridique), aux thèmes les plus récurrents liés à l'institution et aux facteurs déterminant cette couverture médiatique. Il s'agit de vérifier dans quelle mesure elle s'intéresse aux actions effectives du tribunal grâce à l'analyse des décisions qui ont eu la faveur du journal, ce pour quoi 6271 articles ont été passées en revue. Ces données ont permis de mettre en perspective la construction de l'image publique de ce tribunal et la manière dont les médias situent l'institution au sein du système politique brésilien. On en a conclu que le quotidien FSP a modelé une image éminemment politique du STF en exacerbant la personnalisation de l'institution et le profil individuel de ses magistrats, sans compter l'accent mis à outrance sur la judiciarisation anti-corruption.

Mots-clés: Cour Suprême Fédérale du Brésil; médias; couverture politique; couverture juridique; judiciarisation anti-corruption

\section{RESUMEN}

El poder Judicial y la Política en el Brasil Contemporáneo: Un Retrato del Supremo Tribunal Federal a partir de la Cobertura Realizada por el Periódico Folha de S. Paulo

El objetivo del artículo es discutir la visibilidad del Supremo Tribunal Federal de Brasil (STF), examinándola a partir de la cobertura realizada por los grandes medios de comunicación. Buscamos describir la forma en que el periódico Folha de S. Paulo (FSP) retrató la actuación del Supremo durante el período de 1999-2014, enfocando el tipo de cobertura predominante (política o jurídica), los temas más recurrentes en el marco de la institución y los factores que determinan la cobertura. Estudiamos hasta qué punto dicha cobertura acompañaba las acciones que llevaba a cabo el tribunal, examinando cuáles fueron las decisiones que se convirtieron en noticias. Para ello, analizamos el contenido de 6271 noticias y, a partir de estos datos, cuestionamos la construcción de la imagen pública del tribunal y la posición en la que el medio de prensa colocó a la institución en el sistema político brasileño. Concluimos que FSP ha construido una imagen eminentemente política del STF a través de una cobertura que exacerbaba la personalización de la institución y el perfil individual de sus jueces, y enfatizando excesivamente los casos de judicialización anticorrupción.

Palabras clave: Supremo Tribunal Federal de Brasil; medios de comunicación; marco político; marco jurídico; judicialización anticorrupción 